\title{
CHEMICAL CHARACTERISTICS OF BEEF RAWON IN MALANG CITY
}

\author{
Chandra Aditya Darmawan ${ }^{1)}$, Djalal Rosyidi*2), Herly Evanuarini ${ }^{2)}$ \\ 1) Postgraduate Student of Animal Science Faculty, Universitas Brawijaya, Jl. Veteran, Ketawanggede, Kec. \\ Lowokwaru, Malang City, East Java, Indonesia, 65145 \\ ${ }^{2)}$ Lecturer of Animal Science Faculty, Universitas Brawijaya, Jl. Veteran, Ketawanggede, Kec. Lowokwaru, \\ Malang City, East Java, Indonesia, 65145 \\ Email: djalal_tht@ub.ac.id
}

Submitted 27 December 2020; Accepted 12 January 2021

\begin{abstract}
Malang city as a travel destination in East Java has various regional culinary such as rawon. Rawon was a dark soup made from beef broth, kluwak (Pangium edule) paste, sliced beef and various spices, served with rice and often topped with bean sprout. Spices are obtained from natural plants that have a strong aroma and are often used as food mixtures or preservatives. Different ingredients, cooking methods and the heating process will produce different quality of rawon. The quality of rawon in Malang city was still unknown. By knowing the quality of rawon in Malang, parts used in the manufacture of rawon include ribs, brisket, samcan meat and each rawon merchant shop uses a different type. Consumers can choose rawon with the best quality in terms of nutritional value. The purpose of this research was to know the $\mathrm{pH}$, moisture content, fat content, total calories and fatty acid profile of rawon in Malang City. This research used a descriptive quantitative research method. Rawon samples were obtained from several districts in Malang city. The data were analyzed statistically using excel to get the standard deviation based on the method. The results showed that the quality of rawon in Malang city has a $\mathrm{pH}$ of $4.80 \pm 0.22$ to $6.31 \pm 0.16$, moisture content $44.07 \pm 0.15$ to $74.81 \pm 0.16$, fat content $9.86 \pm 0.18$ to $17.62 \pm 0.19$, total calories $88.38 \pm 0.24$ to $201.06 \pm$ 0.14 , rawon consists of 19 saturated fatty acids and 18 unsaturated fatty acids saturated. It can be concluded that rawon beef in Malang was a nutrient dense food and its nutritional content varies depending on the beef used, the recipe and the cooking process.
\end{abstract}

Keywords: Beef; rawon; spices; traditional food 


\section{INTRODUCTION}

The growth of beef consumption in Indonesia was predicted to increase by $9 \%$ in 2022, therefore it will push an equal fulfillment of beef needs in Indonesia. Malang city as a travel destination in East Java has various culinary such as rawon. Rawon was made from slices of beef combined with various spices such as kluwak, shallots, garlic, large red chilies, hazelnut, ladar, coriander, ginger, cumin, bay leaves, kaffir lime leaves, salt and sugar and was usually served with short bean sprouts salted eggs and green onions (Prayoga, et al., 2017). Rawon as traditional food has a taste resulted from the combination of various spices that contain flavonoids, essential oil, tannin and antioxidant activity (Ayuningsih, 2017). Rawon as traditional food was favored by the community because rawon has a delicious taste and also contains needed nutrition which was animal proteins. Apart from having the advantages of high protein content, rawon also has a weakness in the form of its short shelf life (Sundari, et al., 2015).

As one of the traditional foods that have been passed down from generation to generation, the perspective of traditional food was often associated with bad things such as poor processing and lack of hygiene. However, nowadays the public opinion regarding the bad image of traditional food was slowly disappearing. Based on the location survey, it was known that nowadays rawon was available in several restaurants with good arrangement starting from the production site which was kept clean and the availability of water sources for sanitation. The specialty of rawon was its ability to contribute a sufficient amount of protein to fulfill nutrition so that people can consumer beef from rawon because it has a relatively cheap price and a balanced nutritional content. The factors that cause differences in quality among rawon traders include the type of meat used, complete spices, processing and reheating. The standard of beef rawon circulating in Malang City was easily accepted by consumers, was blackish brown, has a savory texture and soft meat, has a fairly large cut of meat and has a high nutrient content needed by the body. The purpose of this study was to determine the quality of rawon circulating in Malang City which was analyzed from $\mathrm{pH}$, moisture content, fat content, total calories, amino acid profile and fatty acid profile.

\section{MATERIALS AND METHODS}

This research was conducted from August 2019 to September 2020 at the Laboratory of Animal Product Technology, faculty of Animal Science, Universitas Brawijaya for the making of rawon products as a control for comparison, Central Laboratory of Biological Sciences Universitas Brawijaya for $\mathrm{pH}$ testing, Laboratory of Food Quality and Safety Testing, Faculty of Agricultural Technology, Universitas Brawijaya for testing moisture content, fat content and total calories and Saraswanti Indo Genetech Bogor Laboratory for fatty acid profile testing.

The research material used was rawon obtained from rawon sellers in Malang City. Rawon was made from beef added with spices such as kluwak, shallots, garlic, large red chilies, bay leaves, ginger, cumin, coriander, hazelnut, turmeric, black pepper, galangal, pepper, lemongrass, salt and sugar. Rawon was obtained from sellers circulating in Malang City and beef was made into rawon as a comparison. The materials used
*Corresponding author:

Djalal Rosyidi

Email: djalal_tht@ub.ac.id

Lecturer of Animal Science Faculty, Universitas Brawijaya, J1. Veteran, Ketawanggede, Kec. Lowokwaru, Malang City, East Java, Indonesia, 65145
How to cite:

Darmawan, C. A., Rosyidi, D., \& Evanuarini, H. (2021). Chemical characteristics of beef rawon in Malang City. Jurnal Ilmu dan Teknologi Hasil Ternak (JITEK), 16 (1), 42-53 
for the analysis were distilled water, $\mathrm{pH} 4$ and $\mathrm{pH} 7$ buffer solutions, methylene blue, alcohol $70 \%$, silica gel, $\mathrm{H}_{2} \mathrm{SO}_{4}$ solution, $\mathrm{K}_{2} \mathrm{SO}_{4}, \mathrm{HgO}, \mathrm{H}_{3} \mathrm{BO}_{3}, \mathrm{NaOH}, \mathrm{HCl} 0.043664$ $\mathrm{N}$, AgNO, glycerol, PCA, peptone, methylated spirits and absolute ethanol or hexane.

The tools used in the making of rawon are stoves, gas cylinders, blenders, pans, basins, spatulas, knives, and cutting boards. The tools used for the analysis are beaker glass, petri dish, Erlenmeyer, magnetic stirrer, oven, waterbath, $\mathrm{pH}$ meter, tensile strength, measuring cup, test tube, test tube rack, volumetric pipette, mortar pestle, spatula, blue tip and electric stove.

\section{Research method}

This research used a quantitative descriptive analysis method with 6 treatments and 2 replications. The treatments are rawon sellers in Malang City. 6 treatments consist of the control treatment (R0), Seller 1 (R1), seller 2 (R2), seller 3 (R3), seller 4 (R4), seller 5 (R5). Samples were taken from Klojen, Blimbing, Lowokwaru, Sukun and Kedungkandang Districts which sell rawon and repeated twice.

\section{Beef rawon processing}

The process of making rawon was based on Prayoga et al., (2017) which was to prepare all the tools and materials. Beef was washed first until clean then boiled until the texture becomes soft and sliced into small pieces. After the beef was boiled, then mash all the spices consist of $14.3 \%$ red onion, $15 \%$ garlic, $11.4 \%$ galangal, $12.3 \%$ hazelnut, $2.5 \%$ coriander, $12 \%$ red chili, $10 \%$ turmeric, pepper $1 \%$ and $10 \%$ ginger using a blender. The oil was heated and the spices that have been mashed are sauteed for
5 min until evenly distributed. Put in the beef that has been sliced then mix with the sauteed spices into the skillet, stirred until evenly distributed. Added three quarters glass of broth, table salt, sugar, broth powder, green onions, and chayote then until evenly distributed. Rawon was cooked for $15-20 \mathrm{~min}$ at $100^{\circ} \mathrm{C}$. The sample being analyzed was first separated between the meat and the broth then the rawon meat was measured in diameter and length then analyzed.

\section{pH analysis}

The $\mathrm{pH}$ analysis was based on SNI 06-6989.11-2004 (2004), in which the $\mathrm{pH}$ meter was calibrated using a buffer solution. For the test sample that has a high temperature, it be adjusted to room temperature. Then it was dried with tissue paper and the electrodes using distilled water. The electrode into the sample until the $\mathrm{pH}$ meter a fixed or constant reading. The reading of the scale or number on the display of the $\mathrm{pH}$ meter.

\section{Moisture content analysis}

Moisture content analysis was of rawon was based on AOAC (2005), namely the drying method using an oven. The porcelain plates were cleaned and dried then given a sample code on each plate then dried in an oven at $105^{\circ} \mathrm{C}$ for 15 min and cooled in a desiccator. Then the porcelain plate was weighed as (W0) and the porcelain plate which the weight was known as (W1). The sample was then dried in an oven at $105^{\circ} \mathrm{C}$ for $12 \mathrm{~h}$ then cooled in a desiccator for 15$30 \mathrm{~min}$ and the contents were weighed. The treatment was repeated until a constant weight (W2) was achieved. The percentage of moisture content was calculated using the following formula:

$$
\text { Moisture Content }(\%)=\frac{(\text { Sample initial weight }- \text { Sample final weight })(g)}{\text { Sample initial weight }} \times 100 \%
$$

\section{Fat content analysis}

Fat content was analyzed based on SNI 2908 (2013), which the Soxhlet method to calculate crude fat and insoluble fat in water. After the preparation of tools and ingredient each sample was mashed and 
wrapped using aluminum foil and dried in the oven. Sample was weighed then put it in a sterile fat flask then added by petroleum ether. The sample was refluxed for $\pm 10 \mathrm{~min}$ until there was an extract formed. The extract was dried using an oven at $100^{\circ} \mathrm{C}$ for
$1 \mathrm{~h}$ for the cooling process, the flask containing the extract was put in a desiccator for $\pm 20 \mathrm{~min}$. Then the extract was weighed to obtain the fat value in the sample. The fat content in the sample was calculated using the formula:

$$
\text { Fat Content }=\frac{\text { Fat weight }- \text { Empty flask weight }}{\text { Sample weight }} \times 100 \%
$$

\section{Total calorie analysis}

The total calorie test was based on Pritasari et al., (2017), which was to determine the calorimeter of the bomb calorimeter's calorific capacity which begins with weighing 1 benzoic acid tablet with an analytical balance. The benzoic acid tablet was inserted into the sample bowl in the bomb then a heating wire was attached to the two electrodes with a wire length of $10 \mathrm{~cm}$ and it was ensured that the wire exactly touches the surface of the benzoic acid. The calorimeter bomb was tightly closed and filled with oxygen gas until the pressure on the manometer shows a pressure of $20 \mathrm{~atm}$. The calorimeter bucket was filled with $2 \mathrm{~L}$ of water then the temperature in the bucket was adjusted to $\pm 1.5^{\circ} \mathrm{C}$ below room temperature. The bucket into the calorimeter then the bomb into the bucket and instal the thermometer.

The calorimeter bomb was left for 4-5 min while the automatic controller adjusts the temperature of the panel to balance the temperature of the water in the bucket. Each minute the water temperature was recorded until it reaches a constant temperature. Every $20 \mathrm{~s}$ after the combustion the temperature of the bucket rise, then the calorimeter was opened and the bomb was removed from the bucket. The solution was then titrated with $0.0725 \mathrm{~N}$ $\mathrm{Na}_{2} \mathrm{CO}_{3}$ with methyl red indicator. The endpoint of the titration was indicated by the appearance of pink color.

The volume of $0.0725 \mathrm{~N} \mathrm{Na}_{2} \mathrm{CO}_{3}$ was needed to calculate the correction factor $\Delta \mathrm{U} 1$. The length of the burnt wire was measured in $\mathrm{cm}$. This wire length data was used to calculate the correction factor $\Delta \mathrm{U} 2$.
Calorimeter calorific capacity was calculated using the following formula:

$$
\Delta \mathrm{UT}=-\frac{(\mathrm{C} . \Delta \mathrm{T}-\Delta \mathrm{U} 1-\Delta \mathrm{U} 2)}{\mathrm{m}}
$$

\section{Fatty acids profile analysis}

Analysis of fatty acid profile was based on Okarini et al., (2019), first a gas chromatography (GC) device and the sample was prepared. Rawon was grounded and dried in an oven at $50^{\circ} \mathrm{C}$ for $12 \mathrm{~h}$. The dried sample was then mashed using a pestle mortar into flour and filtered using a membrane $(250 \mu \mathrm{m}) .100 \mathrm{mg}$ of the fine sample with $1 \mathrm{~mL}(1000 \mu \mathrm{L})$ of absolute methanol or hexane, then centrifuged at $15,000 \mathrm{rpm}$ for $5 \mathrm{~min}$ at room temperature. $100 \mu \mathrm{L}$ of supernatant was taken and added to $900 \mu \mathrm{L}$ of absolute methanol, then centrifuged at $15,000 \mathrm{rpm}$ for $5 \mathrm{~min}$ at room temperature.

The resulting supernatant then be used directly and was ready to be injected into the gas chromatography GC. The amount of supernatant that must be injected was $1 \mu \mathrm{L}$. Samples were extracted using 1 set of Agilent Technologies 6890 N (G.1540M) gas chromatography (GC) equipment (Palo Alto, CA, USA) connected to a detector (Agilent Technologies 5973 Inert Mass Selective Detector) to generate data, equipped with HP5MS column (id. $30 \mathrm{~m} \mathrm{x}$ $0.32 \mathrm{~mm}$ ).

\section{Data analysis}

Obtained data were analyzed statistically using Microsoft Excel to find the average value and standard deviation. The design used was quantitative descriptive analysis. At this stage the results of the 
analysis and data processing that have been carried out will be discussed more fully descriptively in order to obtain conclusions.

\section{RESULTS AND DISCUSSIONS}

\section{pH Value}

$\mathrm{pH}$ value as an indicator to determine the quality of beef was related to lactic acid bacteria in the beef twassue. The average $\mathrm{pH}$ value of rawon can be seen in Table 1 . Based on the research results in Table 1 , it was known that the $\mathrm{pH}$ of rawon has a different mean value. The average $\mathrm{pH}$ value ranges from 4.80-6.31. The lowest $\mathrm{pH}$ value produced by seller 2 (R2) in Blimbing was 4.80 .

The highest $\mathrm{pH}$ value produced by seller 1 (R1) in Klojen District was 6.31. The rawon $\mathrm{pH}$ value from seller 3 (R3) follows the $\mathrm{pH}$ standard which was 5.84 (5.4-5.8). This result was consistent with Lawrie (2003) study which states that based on the SNI value, the $\mathrm{pH}$ value of fresh beef ranges from 5.4-5.8. While the $\mathrm{pH}$ value of rawon spices ranges from 4.11-4.22 (Ayuningsih, 2017). This was in line with the research of Pusudarsono et al., (2015) which states that sugar containing sucrose will affect the value of the resulting $\mathrm{pH}$, so that if sugar was given in the manufacture of food it can increase the $\mathrm{pH}$ value. The use of spices in the manufacture of rawon has benefits in inhibiting the growth of natural microorganisms in the food system. Many factors can determine the final $\mathrm{pH}$ value of beef starting from environmental factors, treatment before and after slaughter, species, age, muscle type and muscle glycogen. The $\mathrm{pH}$ of rawon beef according to SNI was 5.45.8 .

\section{Moisture content}

Moisture content describes the content of free water contained in food ingredients. Based on the results of research and statistical analysis, it was known that the moisture content of rawon varies. The average moisture content value of rawon can be seen in Table 2.

Table 1. Average $\mathrm{pH}$ value of rawon in Malang City

\begin{tabular}{cc}
\hline Sample Code & $\mathrm{pH} \pm \mathrm{SD}$ \\
\hline R0 & $5.99 \pm 0.14$ \\
R1 & $6.31 \pm 0.16$ \\
R2 & $4.80 \pm 0.22$ \\
R3 & $5.84 \pm 0.21$ \\
R4 & $5.74 \pm 0.23$ \\
R5 & $6.08 \pm 0.24$ \\
Mean & $4.80-6.31$ \\
\hline
\end{tabular}

Table 2. Average value of rawon moisture content in Malang City

\begin{tabular}{cc}
\hline Sample Code & Moisture Content $(\%) \pm$ SD \\
\hline R0 & $58.14 \pm 0.14$ \\
R1 & $70.57 \pm 0.17$ \\
R2 & $74.81 \pm 0.16$ \\
R3 & $44.07 \pm 0.15$ \\
R4 & $64.99 \pm 0.15$ \\
R5 & $61.76 \pm 0.18$ \\
Mean & $44.07-74.81$ \\
\hline
\end{tabular}

Based on the research results in Table 2, it was known that the moisture content of rawon in Malang City ranges from 44.07$74.81 \%$. The average value of moisture content was categorized as normal. According to research by Hernando et al., (2015), the moisture content value of beef according to SNI was not more than $80 \%$. 
The value of moisture content was related to microorganisms such as bacteria and fungi that are commonly found in food.

According to Purnomo, (2004) bacteria and fungi will grow if food has a moisture value above $85 \%$. This value indicates that the rawon being sold has a good quality because the value of the moisture content was still below the maximum value of $80 \%$. The lowest moisture content value was produced by seller 3 (R3) in Lowokwaru District, which was $44.07 \%$. The low moisture content value for seller 3 in Lowokwaru District was due to the use of spices that are more complete than other sellers, resulting in a low moisture content value.

The highest moisture content value was produced by seller 2 (R2) in Blimbing District, which was $74.81 \%$. The high moisture content value in $\mathrm{R} 2$ was because the seller does not use spices in the form of bay leaves. Bay leaves contain chitosan which can bind water and prevent damage, therefore, other efforts are needed to extend the shelf life and prevent damage, one of which was with the addition of spices.
According to Rahayu, (2000), traditional spices such as rawon, curry and opor have a low moisture content of $30-40 \%$. The addition of salt to spices can also reduce the value of moisture content in food ingredients because it can affect the amount of water activity and salt which was hygroscopic can absorb water from the meat tissue. According to research by Ayuningsih (2017) states that the use of rawon spices with a concentration of $12 \%$ and $16 \%$ has a better value than the concentration of $8 \%$ because it will affect the shelf life of rawon. The quality of rawon can be confirmed by knowing the proximate value of low water and fat content, protein content, ash content and high calories which show that the rawon has good quality with long shelf life.

\section{Fat Content}

Fat content was described as the energy source that provides the highest caloric value. The fat content contained in rawon was still high enough which caused it prone to food damage. Based on the research results, the average value of rawon fat content in Malang can be seen in Table 3.

Table 3. Average value of rawon fat content in Malang City

\begin{tabular}{cc}
\hline Sample Code & Fat Content $(\%) \pm$ SD \\
\hline R0 & $11.77 \pm 0.14$ \\
R1 & $17.39 \pm 0.16$ \\
R2 & $10.81 \pm 0.17$ \\
R3 & $9.86 \pm 0.18$ \\
R4 & $12.44 \pm 0.48$ \\
R5 & $17.62 \pm 0.19$ \\
Mean & $9.86-17.62$ \\
\hline
\end{tabular}

Based on the research results in Table 3 , it was known that the fat content of rawon has an average value ranging from 9.86$17.62 \%$. The lowest value of fat content was produced by seller 3 (R3) in Lowokwaru District, which was $9.86 \%$. The highest value of fat content was produced by seller 5 (R5) in Kedungkandang District, which was $17.62 \%$. From the research results, it was known that the value of the fat content between rawon has a significant difference. The difference in the value of rawon fat content was thought to be due to several factors such as the type of raw material used, the amount of spices used and the cooking process. Fat content in rawon will decrease during storage and frequent reheating frequency. Boiling was a process in rawon making that can reduce fat content thereby reducing its nutritional content. This happens because, in the boiling process, the fat will be hydrolyzed into glycerol and fatty acids. Soeparno, (1994) stated that other factors that can reduce fat content are due to 
the ability of several types of bacteria to accelerate the hydrolysis of fat and the oxidation process carried out by oxygen which causes a decrease in fat contents during storage because there was a lot of oxygen at room temperature. Decreasing fat content in rawon has good benefits for the body, such as being able to reduce cholesterol levels, reduce the risk of heart disease and stroke and maintain weight stability (Sundari et al., 2015). Food processing using heat was thought to damage the nutritional content of the material, such as volatile damage due to evaporation.

The volatile compounds found in spices, namely ginger which contain essential oils that can prevent oxidation, extend shelf life and improve taste and flavor (Risfaheri, 2012). The characteristics of the damage that usually occurs in rawon can be identified, such as darker colors, slimy, foul smell from the food, the taste becomes bitter and brown water on the bottom of the meat (Arini, 2017). In addition, the presence of bacteria and fungi can cause rancidity, change of taste to sour and produce an unpleasant odor. Other factors that can affect the reduction of fat levels are moisture, feed, genetics, age, and livestock activity (Soeparno, 2005). The best rawon when observed from the fat content was in traders 3 in Lowokwaro District. If rawon has high levels of fat it can cause health problems such as increased body weight, high cholesterol and cause coronary heart disease (Rahmah and Wirjatmadi, 2017).

\section{Total Calories}

Total calories describe the total amount of energy contained in food used by the body to carry out activities and body functions that are based on the energy needs. The average total calorie in rawon can be seen in Table 4.

Table 4. Average total calories of rawon in Malang City

\begin{tabular}{cc}
\hline Sample Code & Total Calories (kcal) \pm SD \\
\hline R0 & $201.06 \pm 0.14$ \\
R1 & $116.64 \pm 0.16$ \\
R2 & $92.05 \pm 0.18$ \\
R3 & $126.09 \pm 0.19$ \\
R4 & $109.21 \pm 0.21$ \\
R5 & $88.38 \pm 0.24$ \\
Mean & $88.38-201.06$ \\
\hline
\end{tabular}

Based on the research results in Table 4 , it was known that the total calories of rawon have various average values. The average total calorie value ranged from 88.38-201.06 kcal. The lowest total calorie value was produced by seller 5 (R5) in Kedungkandang District, which was 88.38 $\mathrm{kcal}$. The highest total calorie value was produced by seller 3 (R3) in Lowokwaru Subdistrict, which was 126.09 kcal. According to Soeparno, (2005) stated that the high caloric value of rawon was because beef contains essential amino acids that are complete, balanced, and needed by the body. Essential amino acids are amino acids obtained by consuming foods that contain high protein (Winarno, 2008). The essential amino acids include lysine, leucine, isoleucine, threonine, methionine, valine, phenylalanine and tryptophan. The caloric value of rawon was highly influenced by the intracellular fat content in the muscle fibers or so-called marbling. According to research by Suryanto et al., (2017) stated that the beef marbling score was related to high levels of fat in body tissue, high fat content will also result in high marbling. However, the marbling score was usually influenced by the age of the cattle. Cattle that are 2-2.5 years old usually have a low marbling score of $2.5-7.5 \%$. The marbling content was also influenced by the feeding treatment. The 
high caloric value obtained was one of the advantages when consuming rawon to fulfill nutritional adequacy rate. According to research by Erfiza et al., (2018) stated that an increase in fat content will be followed by a high-calorie value contained in food. This was because the fat content was the largest contributor to energy compared to other nutrients. Kiay and Abdullah, (2017) stated that the energy source that contributes the highest caloric value was produced by fat or oil which value reaches $9 \mathrm{kcal}$ so that if the value of the fat content contained in rawon was high, the total caloric value will be comparable. Calorie need varies on everyone, usually depending on age, height and weight. The need for calories in the body needs to be controlled because too many calories in the body can harm health. it may cause health problems such as diabetes, obesity, and increases the risk of heart disease.

\section{Fatty Acids Profile Rawon}

Analysis of the fatty acid profile in rawon was carried out to determine the average amount and type of fatty acids contained so it can be used as a reference for the acceptable quality of rawon for consumers. The average value of the fatty acid profile of rawon can be seen in Table 5 , 6 and 7.

Based on the research results in Table 5 , it was known that fatty acids have 37 types consist of and saturated and unsaturated fatty acids. Based on the research data, there was an increase and decrease in the number of treatments in the first and second repetitions. According to Aisyah et al., (2019) fatty acids can be divided into 2 types based on their chemical structure, including saturated fatty acids, which are fatty acids that only consist of single bonds, have one carbon atom bond, not easily oxidized, stable and will not turn into dangerous compounds. Unsaturated fatty acids are fatty acids which carbon atoms have double bonds and will remain liquid because they have a lower melting point compared to Monounsaturated Fatty Acid (MUFA) and Polyunsaturated Fatty Acid (PUFA). Fatty acids also consist of carbon sequences and act as building blocks in the body.

Table 5. Average value of rawon saturated fatty acids profile in Malang City

\begin{tabular}{ccr}
\hline \multirow{2}{*}{ Number } & saturated fatty acids & fatty acid content (\%) \\
\cline { 3 - 3 } & Butyric acid (C2:0) & average \\
\hline 1 & Caproic acid (C4:0) & 0.001285 \\
2 & Caprylic acid (C6:0) & 0,001285 \\
3 & Capric acid (C8:0) & 0.0028 \\
4 & Undecanoic acid (C11:0) & 0.00605 \\
5 & Lauric acid (C12:0) & 0.00725 \\
6 & Tricanoic acid (C13:0) & 0.07105 \\
7 & Myristic acid (C14:0) & 0.07325 \\
8 & Pentadecanoic acid (C15:0) & 0.3936 \\
9 & Palmitic acid (C16:0) & 0.4525 \\
10 & Heptadecanoic acid (C17:0) & 2.7124 \\
11 & Stearic acid (C18:0) & 0.1120 \\
12 & Arachidic acid (C20:0) & 2.37985 \\
13 & Heneicosanoic acid (C21:0) & 0.2675 \\
14 & Benehic cid (C22:0) & 0,3225 \\
15 & Tricosanoic acid (C23:0) & 0,3525 \\
16 & Lignoceric acid (c24:0) & 0.365 \\
17 & & 0.3725 \\
\hline
\end{tabular}


Table 6. Average value of rawon monounsaturated fatty acids profile

\begin{tabular}{rcr}
\hline \multirow{2}{*}{ Number } & monounsaturated fatty acids & fatty acid content (\%) \\
\cline { 3 - 3 } & Myristoleic acid & average \\
2 & Cis-10-pentadecanoic acid & 0.0644 \\
3 & Palmitoleic acid & 0.05775 \\
4 & Cis-10- heptadecanoic acid & 0.1918 \\
5 & Trans-9- elaidic acid & 0.1120 \\
6 & Oleic acid & 2.192 \\
7 & Cis-11- eicosanoic acid & 2.19335 \\
8 & Erucic acid & 0.00148 \\
9 & Nervonic acid & 0.00151 \\
\hline
\end{tabular}

Table 7. Average value of rawon polyunsaturated fatty acids profile

\begin{tabular}{ccr}
\hline \multirow{2}{*}{ Number } & polyunsaturated fatty acids & fatty acid content (\%) \\
\cline { 3 - 3 } 1 & Linolelaidic acid & average \\
2 & Linoleic acid & 0.0655 \\
3 & $\gamma$ Linolenic acid & 0.3492 \\
4 & Linolenic acid & 0.0551 \\
5 & Cis11-14- eicosadienoic acid & 0.0551 \\
6 & Cis-8- 11-14- eicosatrienoic acid & 0.00152 \\
7 & Cis11-14-17- eicosatrienoic acid & 0.0120 \\
8 & Arachidonic acid & 0.00132 \\
9 & Cis13-16- dokosadieno acid & 0.0444 \\
10 & EPA & 0.0016 \\
11 & DHA & 0.0041 \\
\hline
\end{tabular}

The highest fatty acid value in raw meat was produced by palmitic acid, which was a saturated fatty acid composed of 16 carbon atoms. Palmitic fatty acid had an increase in the second replication due to cooking at a high temperature for a long time so it was suspected that there was an increase of temperature in the second replication. The properties of fatty acids found in rawon have relatively stable properties despite an increase in temperature. This was due to the nature of saturated fatty acids which are not easily oxidized and will not turn into dangerous compounds.

As an initial product in the process of fatty acid biosynthesis, palmitic acid was widely used in various daily fields such as the cosmetic industry and has a low antioxidant power as a source of calories.
According to research by Ozugul and Ozugul, (2007) stated that saturated fatty acids such as palmitic, stearic and meristic acids have advantages compared to unsaturated fatty acids because they are not easily subjected to oxidation, are resistant to transactions, and are more stable. The cooking process of rawon in Malang city was dominated by heating at high temperatures.

The heat processing of rawon was started by boiling which can reduce food nutritional content. Besides, the unsaturated fatty acid content in rawon was easily oxidized (Raharjo, 2006). Oxidation was defined as the interaction between oxygen molecules and all the different substances. In his research, Raharjo, (2006) also added that antioxidants can inhibit the oxidation process by controlling prooxidants and free 
radicals. The antioxidants obtained by rawon are produced from natural flavorforming spices. (Widayat et al., 2017). The highest unsaturated fatty acid value was linoleic fatty acid with a value of $0.3485 \%$. Linoleic fatty acid was a type of essential fatty acid that cannot be produced by the body so it must be consumed from foods that contain high protein sources.

Linoleic fatty acids have various benefits including containing omega-6 which was very important for brain and body development in children. Also, the omega- 6 contained in linoleic fatty acids has other health benefits such as helping to maintain mental health and preventing depression, supporting brain and eye development in the fetus, maintaining heart health by increasing the amount of good cholesterol (HDL), lowering triglyceride levels and blood pressure in the body, maintains healthy bones and prevents inflammation that causes chronic disease (Raff et al., 2007). This was following the research of Harris et al., (2009) which stated that linoleic fatty acids are polyunsaturated fatty acids that are useful to help lower blood pressure, maintain cell membranes and maintain cholesterol balance. The daily consumption of linoleic acid also needs to be limited to a maximum of $12-17 \mathrm{~g}$.

\section{CONCLUSIONS}

The chemical characteristics of rawon circulating in Malang City were different due to the different types of meat used, the complete spices used and the processing process. It can be seen from the physical quality which has an average $\mathrm{pH}$ value of 4.80-6.31, chemically, it has an average moisture content of $44.07-74.81 \%$, fat content of $9.86-17.26 \%$ and total calories of 88.38-201.06 kcal.

\section{REFERENCES}

Aisyah, N. F., Aisyah, N., Kusuma, T. S., \& Widyanto, R. M. (2019). Profil asam lemak jenuh dan tak jenuh serta kandungan kolesterol nugget daging kelinci new zealand white (Oryctolagus cuniculus). Jurnal AlAzhar Indonesia Seri Sains Dan Teknologi, 5(2), 92-100. https://doi. org/10.36722/sst.v5i2.356

Arini, L. D. D. (2017). Faktor-faktor penyebab dan karakteristik makanan kadaluarsa yang berdampak buruk pada kesehatan masyarakat. JITIPARI, 2(1), 15-24.

Association of Official Analytical Chemist. (2005). Official method of analysis of the association of official analytical of chemist. Association of Official Analytical Chemist, Inc.

Ayuningsih, S. F. (2018). Pelestarian rawon nguling sebagai nilai tambah pada pengembangan wisata kuliner tradisional indonesia. Majalah Ilmiah Bijak, 14(1), 108-126. https://doi.org/ 10.31334/bijak.v14i1.64

Badan Standarisasi Nasional. (2004). Air dan Air Limbah. In Cara Uji Derajat Keasaman $(p H)$ dengan Menggunakan Alat $p H$ Meter (11th ed.).

Erfiza, N. M., Hasni, D., \& Syahrina, U. (2018). Evaluasi nilai gizi masakan daging khas Aceh (Sie Reuboh) berdasarkan variasi penambahan lemak sapi dan cuka aren. Jurnal Teknologi Dan Industri Pertanian Indonesia, 10(1), 28-35. https://doi. org/10.17969/jtipi.v10i1.10202

Harris, W. S., Mozaffarian, D., Rimm, E., Kris-Etherton, P., Rudel, L. L., Appel, L. J., Engler, M. M., Engler, M. B., \& Sacks, F. (2009). Omega-6 fatty acids and risk for cardiovascular disease. Circulation, 119(6), 902-907. https:// doi.org/10.1161/CIRCULATIONAH A.108.191627

Hernando, D., Septinova, D., \& Adhianto, K. (2015). Kadar air dan total mikroba pada daging sapi di tempat pemotongan hewan (TPH) Bandar Lampung. Jurnal Ilmiah Peternakan Terpadu, 3(1), 61-67.

Kiay, N., \& Abdullah, S. (2017). Karakteristik kimia dan mutu 
organoleptik instan sagu (metroxylon) sebagai makanan berkalori tinggi. Jurnal Gabung Tropika, 6(3), 162-173. Lawrie, R. . (2003). Ilmu Daging (A. Prakkasi (ed.); 5th ed.). Universitas Indonesia Press.

Okarini, I., Purnomo, H., Radiati, I., \& Suaniti, N. (2019). Analysis profil asam lemak daging ayam petelur afkir yang difermentasi secara tradisional Bali menggunakan gas chromatography-mass spectrometry (GC-MS). Jurnal Kimia, 13(1), 44-52.

Özogul, Y., \& Özogul, F. (2007). Fatty acid profiles of commercially important fish species from the Mediterranean, Aegean and Black Seas. Food Chemistry, 100(4), 1634-1638. https:// doi.org/10.1016/j.foodchem.2005.11.047

Prayoga, O. W., Banindro, B., \& Yulianto, Y. H. (2017). Perancangan website dengan pendekatan fotografi untuk memperkenalkan wisata kuliner khas Kota Surabaya. Jurnal Desain Komunikasi Visual Adiwarna, 1(10), $1-10$.

Pritasari, D., Damayanti, \& Lestari, N. T. (2017). Gizi dalam daur kehidupan. Badan Pengembangan dan Pemberdayaan Sumber Daya Manusia Kesehatan.

Purnomo, B. (2004). Materi Kuliah Mikrobiologi. Universitas Bengkulu.

Purnomo, H. (1994). Dasar-Dasar Pengolahan dan Pengawetan Daging. PT. Gramedia Widisarana Indonesia.

Pursudarsono, F., Rosyidi, D., \& Sri Widati, A. (2015). Pengaruh perlakuan imbangan garam dan gula terhadap kualitas dendeng paru-paru sapi. Jurnal Ilmu Dan Teknologi Hasil Ternak, 10(1), 35-45.

Raff, M., Tholstrup, T., Basu, S., Nonboe, P., Sørensen, M. T., \& Straarup, E. M. (2008). A diet rich in conjugated linoleic acid and butter increases lipid peroxidation but does not affect atherosclerotic, inflammatory, or diabetic risk markers in healthy young men. The Journal of Nutrition, 138(3),
509-514. https://doi.org/10.1093/jn/ 138.3.509

Raharjo, M. (2006). Budidaya tanaman kunyit.

Rahayu, W. P. (2000). Aktivitas antimikroba bumbu masakan tradisional hasil olahan industri terhadap bakteri patogen dan perusak. Buletin Teknologi Dan Industri Pangan, 11(2), 42-48.

Rahma, H. H., \& Wirjatmadi, R. B. (2018). Hubungan asupan zat gizi makro dan profil lipid dengan kejadian penyakit jantung koroner pada pasien lansia di rumah sakit islam jemursari Surabaya. Media Gizi Indonesia, 12(2), 129-133. https://doi.org/10.20473/mgi.v12i2.129 $-133$

Risfaheri. (2012). Diversivikasi produk lada (Piper Nigrum) untuk peningkatan nilai tambah. Buletin Teknologi Pascapanen Pertanian, 8(1), 15-26.

Soeparno. (1994). Ilmu dan Teknologi Daging. Gadjah Mada University Press.

Soeparno. (2005). Ilmu dan Teknologi Daging. Gadjah Mada University Press.

Sundari, D., Almasyhuri, A., \& Lamid, A. (2015). Pengaruh proses pemasakan terhadap komposisi zat gizi bahan pangan sumber protein. Media Penelitian Dan Pengembangan Kesehatan, 25(4), 235-242. https://doi .org/10.22435/mpk.v25i4.4590.235-242

Suryanto, E., Bulkaini, B., Soeparno, S., \& Karda, I. W. (2017). Kualitas karkas, marbling, kolesterol daging dan komponen non karkas sapi bali yang diberi pakan kulit buah kakao fermentasi. Buletin Peternakan, 41(1), 72-78. https://doi.org/10.21059/bulet inpeternak.v41i1.12757

Suwandi. (1989). Kimia Organik Karbohidrat, Lipid dan Protein. Universitas Indonesia.

Widayat, B., Cahyono, Satriadi, H., \& Munfarida, S. (2017). Antioxidant activity and total phenolic content in red ginger (zingiber officinale) based 
drink. International Symposium on Food and Agrobiodiversity, 1-9. https://doi.org/10.29303/aca.v3i1.22
Winarno, F. G. (2008). Kimia Pangan dan Gizi. PT. Gramedia Pustaka Utama. 